\title{
Corrosion Behavior of Noble Metals in Different Oral Media
}

\author{
Turan Yanardag \\ Department of Chemistry Faculty of Science, \\ University of Ankara, 06100 Tandogan, Dogol St. Ankara, Turkey \\ E-mail: tyanardag@ankara.edu.tr
}

\begin{abstract}
In this first study, the corrosion behavior of the noble ( $\mathrm{Au}, \mathrm{Pd}, \mathrm{Rh}, \mathrm{Cu}, \mathrm{Ag}, \mathrm{Pt}, \mathrm{Ir}$ ) metals studied in $0.1 \mathrm{M}$ citric acid (CA), 10\% carbamide peroxide (CP), artificial saliva (AS) and in the presence of CP, mouthwash (MW) and in presence of $\mathrm{AS}$, and $0.1 \mathrm{M} \mathrm{NaCl}$ solutions as oral solution. Electrochemical methods investigated with open circuit potential, impedance spectroscopy, current-potential and linear polarization measurements. Metal electrodes immersed in different oral solutions during a week for the determination of total metal cations. These cations analyzed by ICP-OES/MS. This article outline determined with corrosion tendencies of the noble metals and the amount of these ions passing through the human body. Scanning electron microscope (SEM) images showed that gold surface damaged in the presence of the CP. Additionally, the surface examined with EDS. It is concluded that the corrosion rate of noble metals increased in the presence of carbamide peroxide, due to the additional reactions pathways mediated by hydrogen peroxide anions.
\end{abstract}

Keywords: Noble metals, Pilling-Bedworth, Hydrogen Peroxide, Artificial Saliva, Mouthwash

DOI: $10.7176 / J S T R / 5-4-14$

\section{Introduction}

Noble metals have a wide range of application from health to the aerospace and electronic industries [13]. These metals and their compounds are commonly used both in the medical field and catalysis deterioration [4,5]. In recent years, biomedical researches have proven that noble metals can be active in their elemental form as nanoparticul forms [6]. The latest breakthroughs on biomedical applications have already been summarized in several excellent reviews [7]. According to some research, nanoparticles have been successfully synthesized for gold $(\mathrm{Au})$ [8-10], silver (Ag) [11-12], platinum $(\mathrm{Pt})$ [13-14], palladium $(\mathrm{Pd})$ [15-16]. Also, rhodium $(\mathrm{Rh})$ uses of catalytic activity of $\mathrm{CO}_{2}$ electroreduction catalyzed by single-crystal electrode surfaces of Pt metal[17] and iridium(Ir) [18]. Noble metals and their alloys are still used in dentistry due to the resist oxidation and are not attacked by acids. Only three of the noble metals are commonly used in dental alloys: gold, palladium, and platinum. These metals give noble metal alloys their inert properties in the mouth. Therefore, noble metals are an indispensable material in dentistry. The advantages and disadvantages of these alloys depend on the composition of the metals. For example, Au-Pt-Pd is more advantageous compared to Au-Pd-Pd alloys. Because of Au-Pt-Pd alloy has higher hardness and low cost. In generally, can be also divided into various groups depending on whether the amount of noble metal composition in the alloy is more or less.

Exept for gold, noble metals are exposed to oxidation as active metals [19]. Further, no study has found any cathodic dissolution of gold. Cathodic dissolution was also observed by other authors [20-24]. Noble metals are used in significant reactions in the technology, because their potential higher than the hydrogen. Only gold element found in nature as a pure form. Due to the gold is very difficult to give electrons. Gold is not prone to give electrons. But, if the environment changes it undergoes corrosion. Thus, gold has a higher standard reduction potential $(1.42 \mathrm{~V})$ than the other noble metals. They have oxidation with air oxygen is rather difficult at $1.0 \mathrm{~atm}$ and $25^{\circ} \mathrm{C}$ standard condition. For example, platinum $(1.20 \mathrm{~V})$ can be oxidized more easily than gold. Due to pure noble metal forms are highly toxic against bacteria, particularly human pathogens, they can also behave as transporters that carry drugs efficiently. But, recently, although the great number of articles published in this area, uncertainty regarding their toxicity in human has not been completely clarified yet. It is interesting that most of noble metals have improved performance when they form complexes with different ligands, where they have higher activities than the free ligands. For example, for the last few years, silver has a well-known toxic effect on smaller organisms, but it has no known biological role in the human body. For this reason, corrosion of noble metals has great importance for human health. 
The aim of this study is to determinate the number of ions passing through the different oral solutions. If we know the impact of human metals on human beings, we take some precautions. It is preferred that metals with less corrosion are incorporated into the alloys so that it can cause less harm to human health. Therefore, there are some important noble ( $\mathrm{Au}, \mathrm{Pd}, \mathrm{Rh}, \mathrm{Cu}, \mathrm{Ag}, \mathrm{Pt}, \mathrm{Ir}$ ) metals used in dental alloys. The most commonly used precious dental alloys and their noble metal estimated compositions and other components in dentistry are given in Table 1 . The standard reduction potential for the noble metals and their component was given in Table 2. It follows that $\mathrm{Cu}$ exhibited the weakest activity.

Table 1. Precious dental alloys compositional ranges (wt\%) of noble metal with basic and other components. [28-31]

\begin{tabular}{|c|c|c|c|c|}
\hline Base-metal & Bas & c componenet & Other compor & ent \\
\hline Gold & $\mathrm{Au}$ & $39-98$ & $\mathrm{Zn}$ & $0-10$ \\
\hline & $\mathrm{Pd}$ & $0-33$ & In & $0-16$ \\
\hline & $\mathrm{Ag}$ & $0-32$ & $\mathrm{Ga}$ & $0-9$ \\
\hline & $\mathrm{Pt}$ & $0-29$ & Sn & $0-5$ \\
\hline & $\mathrm{Cu}$ & $0-13$ & $\mathrm{Ti}, \mathrm{Nb}$ & $0-2$ \\
\hline & & & $\mathrm{Ir}, \mathrm{Re}, \mathrm{Ta}, \mathrm{Ru}$ & $<0.001$ \\
\hline Palladium & $\mathrm{Pd}$ & $35-86$ & $\mathrm{Au}$ & $0-10$ \\
\hline & $\mathrm{Ag}$ & $0-40$ & $\mathrm{Zn}$ & $0-9$ \\
\hline & $\mathrm{Sn}$ & $0-16$ & Co & $0-5$ \\
\hline & $\mathrm{Cu}$ & $0-14$ & $\mathrm{Ru}, \mathrm{Rb}, \mathrm{Ir}, \mathrm{B}$ & $<0.001$ \\
\hline & $\mathrm{Ga}$ & $0-9$ & & \\
\hline & In & $0-8$ & & \\
\hline Silver & $\mathrm{Ag}$ & $36-60$ & $\mathrm{Au}$ & $2-20$ \\
\hline & $\mathrm{Pd}$ & $20-40$ & In & $0-16$ \\
\hline & $\mathrm{Cu}$ & $0-18$ & $\mathrm{Zn}$ & $1-6$ \\
\hline & & & Sn & $0-5$ \\
\hline & & & $\mathrm{Ir}, \mathrm{Ru}$ & approx. 0.1 \\
\hline Mercury & $\mathrm{Hg}$ & approx.50 & $\mathrm{Zn}$ & 0.001 \\
\hline & $\mathrm{Ag}$ & $25-35$ & In & 0 - slightly \\
\hline & $\mathrm{Sn}$ & $8-15$ & $\mathrm{Pd}$ & $0-0.5$ \\
\hline & $\mathrm{Cu}$ & $2-14$ & & \\
\hline
\end{tabular}

The corrosion tendencies of some dental metal and alloys in the mouth, artificial saliva and citric acidic solutions, may cause health hazards [32-33]. In this study, the corrosion of noble metals used in dental alloys are researched in different media occur in the mouth with electrochemical potential-time, ACimpedance, current-potential, linear polarization. It was calculated electrochemical mass loss before and after experimental. I was performed Surface analyzes with Scanning Electron Microscopy (SEM) and Energy Dispersive X-ray Spectroscopy (EDS) and study solution with Inductively Coupled Plasma Mass Spectrometry (ICP-MS, NexION 300X, Perkin Elmer). The aim of this study is determining the corrosion resistance of noble metals in different mouth solution and how we can achieve a contribution to the corrosion of the noble metal. 
Table 2. Noble metals and their component reaction with potentials $\left(\mathrm{E}^{\circ}\right)$ at standard conditions $(1.0 \mathrm{~atm}$ and $\left.25 \pm 0.1^{\circ} \mathrm{C}\right)[25-27]$.

\begin{tabular}{lclc}
\hline Reduction & $\begin{array}{c}\mathrm{E}^{\circ} \\
(\mathrm{V} \text { vs. SHE })\end{array}$ & $\begin{array}{l}\text { Half electrochemical } \\
\text { thermodynamic reduction }\end{array}$ & $\begin{array}{c}\mathrm{E}^{\circ} \\
(\mathrm{V} \text { vs. SHE })\end{array}$ \\
\hline $\mathrm{Au}^{3+}(\mathrm{aq})+3 \mathrm{e}^{-}=\mathrm{Au}(\mathrm{k})$ & 1.42 & $\mathrm{Au}(\mathrm{OH})_{2}^{-}(\mathrm{aq})+\mathrm{e}^{-}=\mathrm{Au}(\mathrm{k})+2 \mathrm{OH}^{-}(\mathrm{aq})$ & 0.40 \\
$\mathrm{Pt}^{2+}(\mathrm{aq})+2 \mathrm{e}^{-}=\mathrm{Pt}(\mathrm{k})$ & 1.20 & $\mathrm{Pt}(\mathrm{OH})_{2}(\mathrm{k})+2 \mathrm{e}^{-}=\mathrm{Pt}(\mathrm{k})+2 \mathrm{OH}^{-}(\mathrm{aq})$ & 0.15 \\
$\mathrm{Ir}^{3+}(\mathrm{aq})+3 \mathrm{e}^{-}=\mathrm{Ir}(\mathrm{k})$ & 1.16 & $\mathrm{Ir}_{2} \mathrm{O}_{3}(\mathrm{k})+6 \mathrm{e}^{-}+\mathrm{H}_{2} \mathrm{O}(\mathrm{s})=2 \mathrm{Ir}(\mathrm{k})+6 \mathrm{OH}^{-}(\mathrm{aq})$ & 0.10 \\
$\mathrm{Pd}^{2+}(\mathrm{aq})+2 \mathrm{e}^{-}=\mathrm{Pd}(\mathrm{k})$ & 0.99 & $\mathrm{Rh}(\mathrm{OH})_{3}(\mathrm{k})+3 \mathrm{e}^{-}=\mathrm{Rh}(\mathrm{k})+3 \mathrm{OH}^{-}(\mathrm{aq})$ & 0.0 \\
$\mathrm{Ag}^{+}(\mathrm{aq})+\mathrm{e}^{-}=\mathrm{Ag}(\mathrm{k})$ & 0.80 & $\mathrm{Pd}(\mathrm{OH})_{2}(\mathrm{k})+2 \mathrm{e}^{-}=\mathrm{Pd}(\mathrm{k})+2 \mathrm{OH}^{-}(\mathrm{aq})$ & 0.07 \\
$\mathrm{Rh}^{2+}(\mathrm{aq})+2 \mathrm{e}^{-}=\mathrm{Rh}(\mathrm{k})$ & 0.60 & $\mathrm{AgI}(\mathrm{k})+\mathrm{e}^{-}=\mathrm{Ag}(\mathrm{k})+\mathrm{I}^{-}(\mathrm{aq})$ & -0.15 \\
$\mathrm{Rh}^{3+}(\mathrm{aq})+3 \mathrm{e}^{-}=\mathrm{Rh}(\mathrm{k})$ & 0.80 & $\mathrm{Cu}_{2} \mathrm{O}(\mathrm{k})+\mathrm{H}_{2} \mathrm{O}(\mathrm{s})+2 \mathrm{e}^{-}=\mathrm{Cu}(\mathrm{k})+2 \mathrm{OH}^{-}(\mathrm{aq})$ & -0.36 \\
$\mathrm{Cu}^{2+}(\mathrm{aq})+2 \mathrm{e}^{-}=\mathrm{Cu}(\mathrm{k})$ & 0.35 & & \\
\hline
\end{tabular}

The corrosion tendencies of some dental metal and alloys in the mouth, artificial saliva and citric acidic solutions, may cause health hazards [32-33]. In this study, the corrosion of noble metals used in dental alloys are researched in different media occur in the mouth with electrochemical potential-time, ACimpedance, current-potential, linear polarization. It was calculated electrochemical mass loss before and after experimental. I was performed Surface analyzes with Scanning Electron Microscopy (SEM) and Energy Dispersive X-ray Spectroscopy (EDS) and study solution with Inductively Coupled Plasma Mass Spectrometry (ICP-MS, NexION 300X, Perkin Elmer). The aim of this study is determining the corrosion resistance of noble metals in different mouth solution and how we can achieve a contribution to the corrosion of the noble metal.

\section{Experimental}

For the corrosion tests of noble metals ( $\mathrm{Au}, \mathrm{Pd}, \mathrm{Rh}, \mathrm{Cu}, \mathrm{Ag}, \mathrm{Pt}, \mathrm{Ir}$ ) prepared seven different types solutions as a mouth solution. Firstly, sample wire metals embedded into cylindrical Teflon tube, coating with a polymeric adhesive prepared as a working electrode. Secondly, it was prepared $0.1 \mathrm{M}$ citric acid (CA), mouthwash (widely used in the market, $\mathrm{MW}$ ), 0.1M neutral solution ( $\mathrm{NaCl}$ ), artificial saliva (AS), AS+MW (1:1 v\%) solution, $10 \%$ carbamide peroxide (CP, prepared with $100 \mathrm{~g}$ urea hydrogen peroxide and $0.1 \mathrm{M}$ phosphate buffer $(125,43 \mathrm{~g} / \mathrm{L}, \mathrm{pH}: 6.5)$ up to $1000 \mathrm{~mL})$ and $\mathrm{AS}+\mathrm{CP}(1: 1 \mathrm{v} \%)$ as a study solution. All used chemicals are Merck purity. The composition of MW solution respectively is propylene glycol, sorbitol, poloxamer 407, sodium lauryl sulfate, eucalyptol, benzoic acid, sodium benzoate, methyl salicylate, thymol, sodium saccharin, sodium fluoride (220 ppm), menthol, suclarose, aroma and chloride ion (42053 ppm). In order to measure the mass loss each working electrode was immersed in study solutions in $50 \mathrm{ml}$ glass containers during a week. For corroded noble metal composition of the cation was performed by ICP-MS analysis and surface composition of noble metals with SEM/EDS. Fusayama artificial saliva was used as test enviroment for electrochemical characterization. It consisted of $0.400 \mathrm{~g} \mathrm{NaCl}, 0.400 \mathrm{~g} \mathrm{KCl}, 0.795 \mathrm{~g} \mathrm{CaCl}_{2} \cdot \mathrm{H}_{2} \mathrm{O}, 0.690 \mathrm{~g} \mathrm{NaH}_{2} \mathrm{PO}_{4} \cdot \mathrm{H}_{2} \mathrm{O}$, $0.005 \mathrm{~g} \mathrm{Na}_{2} \mathrm{~S} .9 \mathrm{H}_{2} \mathrm{O}$ and distilled water up to $1000 \mathrm{~mL}(\mathrm{pH}=5,525)$ (Fusayama, Katayori \& Nomoto, 1963). A conventional three-electrode system was adopted, where the noble metals were used as a working electrode, a saturated with $(\approx 4 \mathrm{M}) \mathrm{KCl}$ solution $\mathrm{Ag} / \mathrm{AgCl}$ was used as a reference electrode and a platinum wire was employed as a counter electrode. The temperature of the electrochemical cell was fixed at $37 \pm 1^{\circ} \mathrm{C}$.

Electrochemical measurements were performed using a potentiostat (CHI 660B Electrochemical Workstation Software, Austin, USA), a thermostat (Poly Science, Model 9106, Division of Preston Industries Inc. USA), disc electrode (BAS, RDE-2), corrosion cell and arrangement system consists of a computer used for obtaining the data. Electrodes polished with 2000 sandpaper washed with double distilled water and after washing working electrodes were carried in study solution prepared with double distilled water obtaining electrochemical methods by potential-time, current-potential curves, linear polarization and AC impedance. The electrochemical cell used in this shown in Figure 1. 


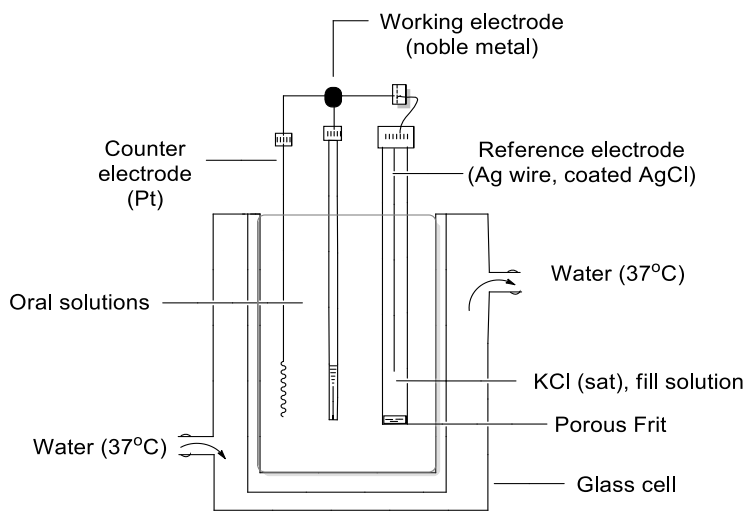

Figure 1. Schematic view of electrochemical cell

The open-circuit potential (OCP) vs time curve was recorded during the working electrode was immersed in each electrolyte for $1200 \mathrm{~s}$ to stabilize the open circuit potential. An alternating AC impedance potential signal of amplitude $\pm 10 \mathrm{mV}$ was used with frequencies in the range of $100 \mathrm{kHz}$ to $0.1 \mathrm{~Hz}$. Current-potential curves were also carried out in previously prepared study solutions. These measurements were conducted by increasing the potential from -0.3 to $+0.3 \mathrm{~V}$ vs. $\mathrm{Ag} / \mathrm{AgCl}$ saturated $(\approx 4$ M) with $\mathrm{KCl}$ solution, using a scanning rate of $1 \mathrm{mV} \mathrm{s}^{-1}$. Using the dedicated CorrWare software of the electrochemical test system, zero current potential $\left(\mathrm{E}_{\text {corr }}\right)$, and the corrosion current density ( $\mathrm{i}_{\text {corr }}$ ), were determined by Tafel analysis of both anodic and cathodic branches of the polarization curves for a range of $\pm 150 \mathrm{mV}$ around the open circuit potential. All the electrochemical experiments are performed three times. These replications were not sufficient to carry out statistical analysis, but the reproducibility of the measured data.

\section{Discussion}

Electrochemical system used in this study. This system has been performed by potential-time (OCP), AC-impedance and current-potential curves, respectively. Generally, metals immersed in any electrolyte solution, the potential can be shiftted the different direction. If the potential shift at the positive direction with time, the metal surface is coated with a protective layer and. It can also be called that metal surface is passive. So the corrosion rate is expected to decrease. Conversely, if the potential shift at the negative direction with time, there is no protective layer on the metal surface and it show that metal is corroded. In current-potential curves, if the lines slope is higher, the polarization resistance is smaller and the corrosion rate is also higher too. Considering the contrary, if the lines slope is smaller, the polarization resistance is higher and the corrosion rate is also decrease in solution. Moreover, when open circuit potential of electrode change at the positive direction in the studied solutions including the chemicals it affects as anodic inhibitor. If the open circuit potential of electrode with change at the negative direction in these solutions it effects as anodic inhibitor. But if it is act as both anodic and cathodic inhibitor, it can be not any change at the open circuit potential [34-37]. Electrochemical methods performed with potential-time (OCP), AC-impedance, current-potential curves in different oral solution for noble (Au, $\mathrm{Pd}, \mathrm{Rh}, \mathrm{Cu}, \mathrm{Ag}, \mathrm{Pt}, \mathrm{Ir})$ metals. Data obtained from these curves were repeated for each experiment obtaining average data at least three times in terms of the reliability of this data. Corrosion rates $\left(\mathrm{i}_{\text {corr }}\right.$, $\left.\mu \mathrm{A} \mathrm{cm}{ }^{-2}\right)$, anodic $\left(\beta_{\mathrm{a}}, \mathrm{mV} / \mathrm{dec}\right)$ and cathodic $\left(\beta_{\mathrm{c}}, \mathrm{mV} / \mathrm{dec}\right)$ Tafel slopes and equilibrium potential $\left(\mathrm{E}_{\text {corr }}\right.$, Volt) corrosion parameters obtained from current-potential curves. In linear polarization method, linear polarization resistance $\left(\mathrm{R}_{\mathrm{LP}}\right)$ calculated from slopes of linear polarization lines obtained from currentpotential curves at the near the equilibrium potential $\left(\mathrm{E}_{\text {corr }}\right)$. Linear equation, including $\mathrm{y}$-axis and $\mathrm{x}$-axis, $\mathrm{y}=\mathrm{mx}+\mathrm{n}$ from near the equilibrium $\left(\mathrm{E}_{\mathrm{corr}}\right)$ potential in the current-potential curves by scanning in anodic $(+10 \mathrm{mV})$ and cathodic direction $(-10 \mathrm{mV})$ and $\mathrm{R}^{2}>0.998 \pm 0.001$. The closer the value of $\mathrm{R}^{2}$ is to 1 , the more accurate the linear equation. There is a relationship between " $\mathrm{m}$ " and $\mathrm{R}_{\mathrm{LP}}$. The slope of the linear equation " $m$ " gives us the inverse of the linear polarization $\left(R_{L P}\right)$ resistance. That is $m=1 / R_{L P}$ equation and according to Ohm Law $\Delta \mathrm{I} / \Delta \mathrm{E}=1 / \mathrm{R}_{\mathrm{LP}}$ equation can be shown in Stern-Geary equation Eq.1. 


$$
\boldsymbol{i}_{c o r r}=\frac{\beta_{a} \times \beta_{c}}{2,303\left(\beta_{a} \times \beta_{c}\right)} \times \frac{\Delta \boldsymbol{I}}{\Delta \boldsymbol{E}}=\frac{\beta_{a} \times \beta_{c}}{2,303\left(\beta_{a} \times \beta_{c}\right)} \times \frac{1}{\mathrm{R}_{\mathrm{LP}}}
$$

In this equation $\beta_{\mathrm{a}}$ shows the anodic, $\beta_{\mathrm{c}}$ cathodic Tafel slopes and $\mathrm{R}_{\mathrm{LP}}$ linear polarization resistance. Corrosion rate was also calculated from this equation. In this way, the corrosion rates found from Tafel extrapolation and from the Stern-Geary equation. It was noticed that they are approximately the same. This shows us that $\mathrm{R}_{\mathrm{LP}}$ values calculated from linear polarization lines are very reliable resistance. For this reason, these $R_{L P}$ values can also be use in AC-impedance diagrams instead of the charge transfer $\left(R_{c t}\right)$ resistance, but in some stuation $R_{p}$ resistance value not equal to $R_{c t}$ charge transfer resistance. Rct resistance can only be used in semi-circular curves, because of the semi-circle diameter is equal the charge transfer $\left(\mathrm{R}_{\mathrm{ct}}\right)$ resistance. That is, in the semicircle curves the polarization resistance is equal to the charge transfer resistance. AC-impedance curves for gold presence of $\mathrm{CP}$ is half a circle. Therefore, corrosion mechanism is under charge transfer control shown in Fig.2b. Electrode capacitance (C) values are calculated from Eq. 2 .

$$
\boldsymbol{C}=\frac{1}{2 \pi f_{Z^{\prime \prime}(\max )}} \times \frac{1}{\mathrm{R}_{\mathrm{p}}}
$$

In this equation, $\boldsymbol{f}$ shows the frequency when the $\mathrm{Z}$ " (imaginer) $\mathrm{y}$-axis value is maximal. The $\mathrm{C}$ value and $R_{p}$ values are inverse proportion. If the $R_{p}$ value increases, the $C$ value decreases in study solution. Hence, the corrosion rate increases. In this equation $R_{p}$ resistance of gold, $\approx 160 \Omega . \mathrm{cm}^{2}$, is equal to $R_{c t}$ in CP solution. In this study, mass loss was chosen as an indication of corrosion behavior. Corrosion rates presented as mass per unit area $\left(\mathrm{mg} \mathrm{cm}^{-2}\right)$ calculated from Eq.3.

$$
i_{c o r r}=\frac{\Delta m \times \mathrm{n} \times \boldsymbol{F}}{\Delta \mathrm{t} \times \boldsymbol{M} \times \boldsymbol{A}}
$$

Where $\Delta m$ is differences of the mass loss $(\mathrm{mg}) ; n$ is the electron number; $F$ is the Faraday constant $(96500$ $\mathrm{C} / \mathrm{mol}) ; \Delta t$ is the mass loss with time; $M$ is the molar mass of metals $\left(\mathrm{g} \mathrm{mol}^{-1}\right) ; A$ is the surface area $\left(\mathrm{cm}^{2}\right)$; 

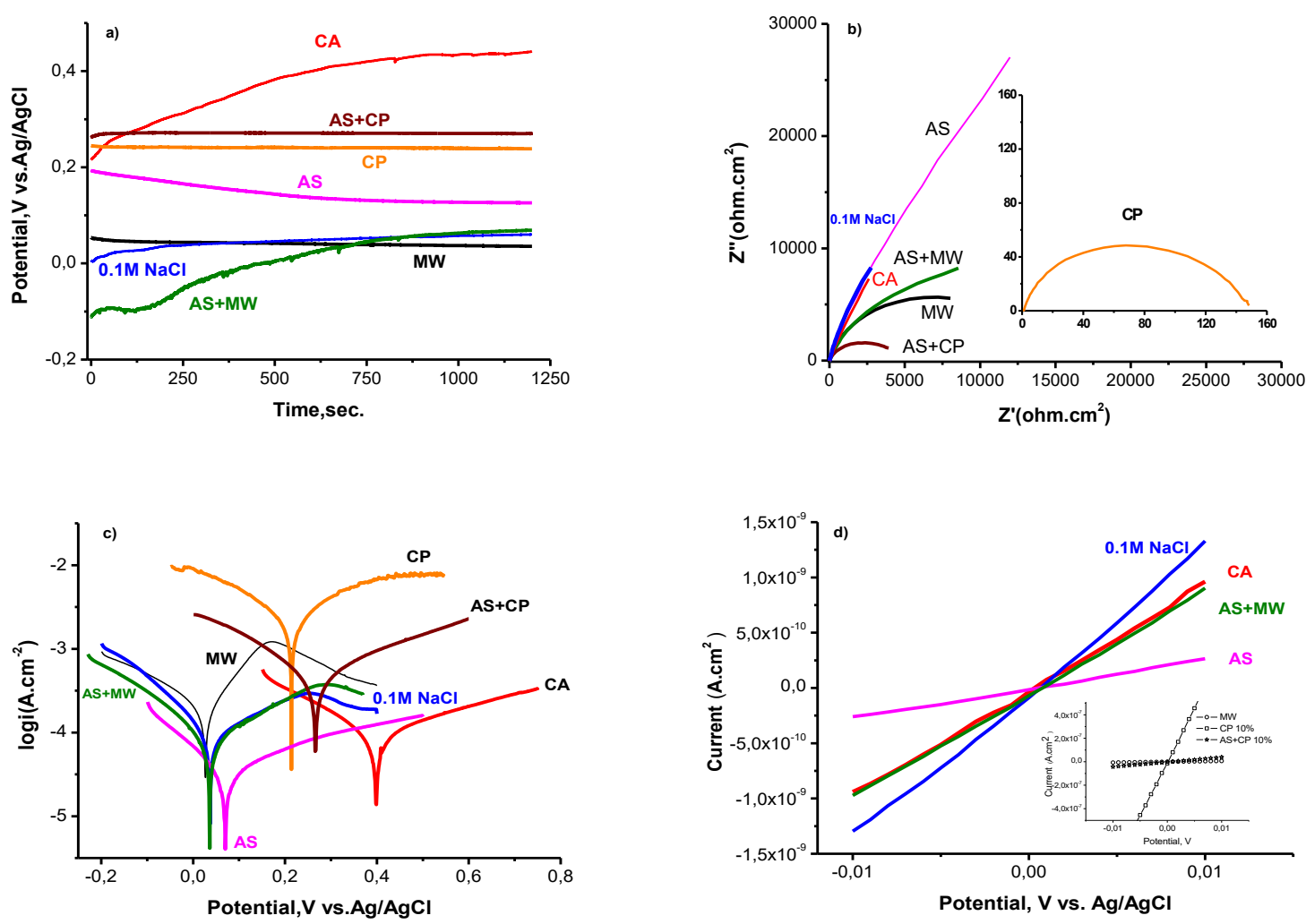

Figure 2. Electrochemical experimental was obtained by a) Potential-time b) AC-empedans (EIS) c) Currentpotential (Tafel) curves and d) Linear polarisation (LP) curves measured by potentiodynamic polarization on gold in $0.1 \mathrm{M}$ citric acid (CA), mouth wash (widely used in the market, $\mathrm{MW}), 0.1 \mathrm{M} \mathrm{NaCl}$ solution, artificial saliva (AS), AS+MW (1:1 v\%) solution, 10\% carbamide peroxide (CP) and AS+CP (1:1 v\%) solutions.

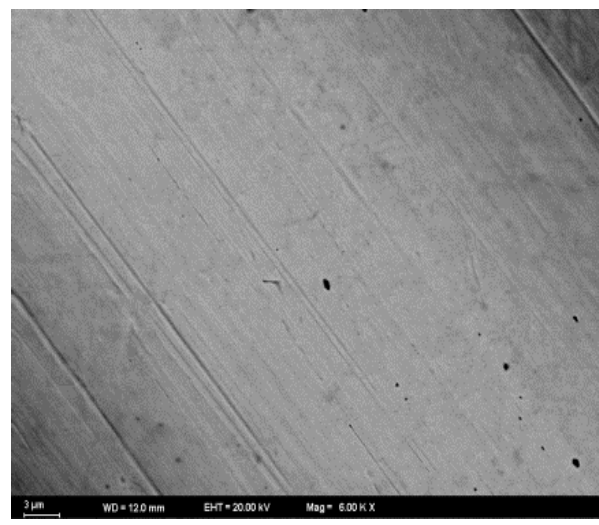

a)

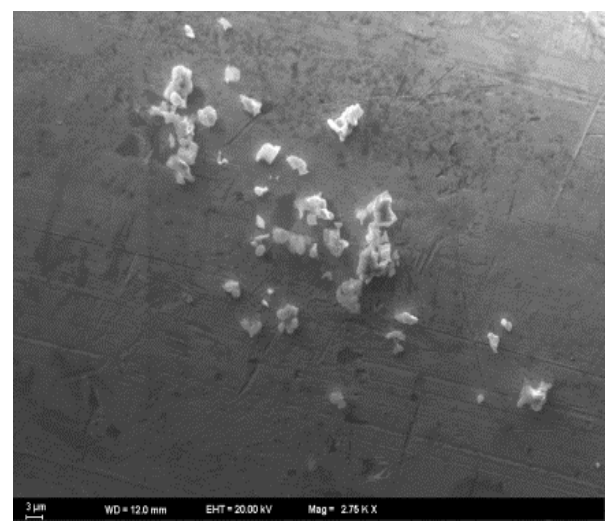

b)

Figure 3. Scanning electron microscopy images (SEM) for two types of gold surfaces a) absence and b) presence of $10 \%$ carbamide peroxide (CP)

Gold metal immersed in $10 \%$ carbamide peroxide (CP) showed that the protective layer occurred on the surface (Fig.3). 10\% carbamide peroxide (CP) breaks down into hydrogen peroxide and urea, with hydrogen peroxide being the active bleaching agent. Bleaching product containing $\mathrm{CP}$ yields 
approximately $3.5 \%$ hydrogen peroxide. This compound preparations for the whitening of teeth a bleaching agent widely used in dentistry. This compound is also used in some cosmetics and pharmaceuticals. Scanning electron microscopy images (SEM) obtained for gold in the absence and presence of CP shown in Fig.3. Corrosion parameters determined for gold and for the other are given under the same conditions. Corrosion rates, anodic $\left(\beta_{\mathrm{a}}\right)$ and cathodic $\left(\beta_{\mathrm{c}}\right)$ Tafel slopes and equilibrium potential, mass loss, $\mathrm{C}$ capacity, measurement of $\mathrm{pH}$ and conductivity before and after experiments parameters given in Table 3.

It can be compared with corrosion rates obtained from the current-potential curves by Tafel extrapolation to the corrosion potential (Table 4) [38]. Lowering of mass losses indicated that the corrosion resistance was improved on the noble metal surface because of the protective oxide layer. Indeed, this view is also confirmed by surface analysis, while metal dissolution occurred in different dental solution, the oxygen increases on its surface given in Table 4. Mass loss of metals is higher it showed that corrosion products of metals are soluble. For this reason, noble metals do not suitable for using in carbamide peroxide solution and tooth bleaching agent solution given in Table 4. If the corrosion products are less soluble, this character is positive effect while using their in this solution. If the hydrogen peroxide used instead of carbamide peroxide, it should be much more corrosive [39-41]. If the corrosion rate calculated from mass loss, it is higher than calculated other methods, it can be expressed increasing corrosion rates of metal with time. Because, corrosion rate calculated from mass loss obtained average corrosion rate of metals in a week. For example, the corrosion of copper in AS+MW and gold in $\mathrm{CA}, \mathrm{MW}, \mathrm{NaCl}$ and $\mathrm{AS}$ showed a bad character as a dental metal. Gold and platinum are passive in AS, but copper is not [42]. In general, the metals in the aqueous solution are absolutely more or less soluble. Therefore corrosion is inevitable. If the noble metal is corroded in the oral solution, it gives some ions or compound to the solution. Especially the ions of these transition elements can be harmful to health. For example, the lower number of ions passing through the solution, the less allergic diseases can be occurred. It can be taken a simple precaution depending on which ion and how many ions pass through the solution. This precaution is either corrosive or how the environment can be avoided reduced or material change is necessary. If the corrosion products are not soluble, they would be less allergic. Composition of the $\mathrm{Au}, \mathrm{Pd}$ and $\mathrm{Rh}$ metal surface obtained by EDX and cation concentrations in the very corrosive solution obtained by ICPMS were given in Table 4 and 5 respectively. In higher corrosive solution, corrosion products of gold are not soluble because of gold ions are not seen in these solutions (Table 5) [42]. For this reason, corrosion products of gold will be higher valence oxide (Pilling-Bedworth ratio higher and porous) and $\mathrm{CP}$ or reduced products of $\mathrm{CP}$ can be adsorb on the gold metal surface (Eq.4). Corrosion of the other noble metals are also higher in the same solutions, but corrosion products of palladium, gold and copper will be less soluble. Noble metal cation concentrations as ppm obtained in higher corrosive solutions were given in Table 5. Corrosion products expected in this very corrosive solution at the higher valance $\left(\mathrm{PdO}_{3}{ }^{-}\right.$and $\left.\mathrm{RhO}_{4}{ }^{2-}\right)$ [19]. On the iridium surface can be form $\mathrm{Ir}_{2} \mathrm{O}_{3}$ and $\mathrm{IrO}_{2}$. Iridium oxide at the other side $\left(\mathrm{IrO}_{2}\right)$ oxidized to the $\mathrm{IrO}_{3}{ }^{-}$and $\mathrm{IrO}_{4}^{-2}$ in tooth bleaching agent (CP) containing solutions [19]. Pilling-Bedworth ratio of $\mathrm{IrO}_{2}$ is very high (8.3). For this reason, higher corrosion rate is measured. This case is compatible with Pourbaix diagrams [19]. Corrosion rate calculated from mass loss the same solution comparable with the other methods, but corrosion rates calculated from mass loss are smaller than obtained other methods (Table 4). Only copper metal showed different behavior in the CP containing solution. It showed that less corrosion. Thus, these data showed that gold-copper alloys can be higher resist against to corrosion in bleaching agent material (CP) than pure gold metal. EDX analysis (Table 4) showed that pure copper surface coated with oxide in $\mathrm{CP}$ material, but it coated with dissolved phosphate $\left[\mathrm{Cu}_{3}\left(\mathrm{PO}_{4}\right)_{2}\right]$ waited in $\mathrm{AS}$ and $\mathrm{CP}+\mathrm{AS}$ solution [26]. 
International Journal of Scientific and Technological Research

ISSN 2422-8702 (Online), DOI: 10.7176/JSTR/5-4-14

Vol.5, No.4, 2019

www.iiste.org

Table 3. Corrosion parameters of noble metals obtained in $10 \%$ carbamide peroxide (CP), mouthwash (MW), artificial saliva (AS), $0.1 \mathrm{M} \mathrm{NaCl}, 0.1 \mathrm{M}$ citric acid (CA), CP+AS ( 1:1) and AS+MW (1:1) solution, (before) and after $\mathrm{pH}$ and conductivity (cond.) values measured (before) and after experiment.

(ML:Mass Loss, SG:Stern-Geary)

\begin{tabular}{|c|c|c|c|c|c|c|c|c|c|c|c|}
\hline \multirow{2}{*}{ Me } & \multirow[b]{2}{*}{ Solution } & \multirow[b]{2}{*}{$\begin{array}{l}\mathbf{E}_{\text {corr }} \\
(\mathrm{V})\end{array}$} & \multirow[b]{2}{*}{$\begin{array}{l}\boldsymbol{\beta}_{c} \\
\left(\mathrm{mV} \cdot \mathrm{dec}^{-1}\right)\end{array}$} & \multirow[b]{2}{*}{$\begin{array}{l}\boldsymbol{\beta}_{a} \\
(\mathrm{mV} \mathrm{dec} \\
\end{array}$} & \multirow[b]{2}{*}{$\begin{array}{l}\mathbf{R}_{p} \\
\left(\Omega \cdot \mathrm{cm}^{2}\right)\end{array}$} & \multirow[b]{2}{*}{ pH } & \multirow[b]{2}{*}{$\begin{array}{l}\mathbf{C} \\
\left(\mu \mathrm{F} \mathrm{cm}{ }^{-2}\right)\end{array}$} & \multirow[b]{2}{*}{$\begin{array}{l}\text { Cond. } \\
\left(\mathrm{mS} \mathrm{cm}^{-2}\right)\end{array}$} & \multicolumn{3}{|c|}{ Corrosion Rate $\left(i_{\text {corr }}\right)$} \\
\hline & & & & & & & & & $\begin{array}{l}\mathbf{M L} \\
\left(\mathrm{mg} \mathrm{cm}^{-2}\right) \\
\end{array}$ & $\begin{array}{l}\text { SG } \\
\left(\mu \mathrm{A} \mathrm{cm} \mathrm{cm}^{-2}\right)\end{array}$ & $\begin{array}{l}\text { Tafel } \\
\left(\mu \mathrm{A} \mathrm{cm}^{-2}\right)\end{array}$ \\
\hline \multirow[t]{7}{*}{ Ag } & $\mathrm{CP}$ & 0.345 & 2594 & 782 & 13 & (6.5) 6.7 & 5810 & (35) 35.5 & 21 & 21725 & 19607 \\
\hline & $\mathrm{CP}+\mathrm{AS}$ & 0.360 & 585 & 1478 & 21 & (6.8) 6.8 & 176 & (22) 29 & - & 7628 & 8631 \\
\hline & $\mathrm{CA}$ & 0.060 & 130 & 137 & 5880 & (2.1) 2.0 & 229 & (3.3) 3.4 & - & 4.9 & 4.9 \\
\hline & AS+MW & 0.050 & 95 & 85 & 9418 & (4.3) 4.2 & 143 & (1.8) 1.7 & 1.1 & 1.7 & 2.1 \\
\hline & AS & 0.000 & 139 & 137 & 17405 & (5.2) 5.3 & 105 & (2.85) 2.8 & 1.2 & 1.8 & 1.7 \\
\hline & MW & 0.020 & 112 & 253 & 23483 & (4.5) 4.5 & 57 & (1.5) 1.5 & 1.3 & 1.4 & 1.4 \\
\hline & $0.1 \mathrm{M} \mathrm{NaCl}$ & 0.000 & 139 & 137 & 17405 & (6.4) 6.9 & 70 & (10.5) 10 & - & 0.7 & 0.8 \\
\hline \multirow[t]{7}{*}{ Pd } & $\mathrm{CP}$ & 0.210 & 558 & 325 & 6 & (6.5) 6.7 & 29 & (35) 35 & 2.6 & 14066 & 7732 \\
\hline & $\mathrm{CP}+\mathrm{AS}$ & 0.215 & 494 & 427 & 95 & (6.8) 6.8 & 5.4 & (22) 29 & 1.7 & 1037 & 1045 \\
\hline & MW & 0.300 & 147 & 240 & 7199 & (4.5) 3.9 & 187 & (1.5) 1.4 & 1.0 & 4.9 & 5.5 \\
\hline & $0.1 \mathrm{M} \mathrm{NaCl}$ & 0.260 & 147 & 240 & 7199 & (6.4) 9.0 & 42.7 & (10.5) 9.9 & 2.9 & 1.1 & 1.0 \\
\hline & $\mathrm{AS}+\mathrm{MW}$ & 0.310 & 120 & 203 & 32004 & (4.3) 4.2 & 42 & (1.8) 1.8 & 1.0 & 1.0 & 1.0 \\
\hline & AS & 0.275 & 121 & 295 & 40411 & (5.2) 5.5 & 33 & (2.9) 2.8 & 0.9 & 0.9 & 0.9 \\
\hline & $\mathrm{CA}$ & 0.475 & 105 & 181 & 51346 & (2.1) 2.1 & 26 & (3.3) 3.3 & 0.8 & 0.6 & 0.8 \\
\hline \multirow[t]{7}{*}{ Pt } & $\mathrm{CP}$ & 0.185 & 1838 & 228 & 13 & (6.5) 6.7 & 26.7 & (35) 35 & - & 6185 & 6827 \\
\hline & $\mathrm{CP}+\mathrm{AS}$ & 0.230 & 239 & 255 & 625 & (6.8) 6.8 & 0.01 & (22) 29 & - & 77.4 & 85.7 \\
\hline & $\mathrm{CA}$ & 0.540 & 153 & 235 & 14541 & (2.1) 2.0 & 92.5 & (3.3) 3.3 & - & 2.7 & 2.8 \\
\hline & MW & 0.420 & 177 & 159 & 13178 & (4.5) 4.0 & 102 & (1.5) 1.4 & - & 2.8 & 2.8 \\
\hline & AS & 0.280 & 150 & 258 & 18522 & (5.2) 5.5 & 72.6 & (2.9) 2.8 & - & 2.2 & 2.2 \\
\hline & $\mathrm{AS}+\mathrm{MW}$ & 0.265 & 131 & 252 & 19615 & (4.3) 4.2 & 68.6 & (1.8) 1.8 & - & 1.9 & 1.9 \\
\hline & $0.1 \mathrm{M} \mathrm{NaCl}$ & 0.325 & 134 & 243 & 18351 & (6.4) 9.0 & 73 & (10.5) 9.9 & - & 2.0 & 2.0 \\
\hline \multirow[t]{7}{*}{$\mathbf{R h}$} & $\mathrm{CP}$ & 0.200 & 266 & 393 & 17 & (6.5) 6.7 & 249 & (35) 37.8 & 0.2 & 4067 & 4130 \\
\hline & $\mathrm{CP}+\mathrm{AS}$ & 0.200 & 338 & 296 & 19 & (6.8) 6.8 & 146 & (22) 29.5 & 0.7 & 3625 & 3699 \\
\hline & $\mathrm{CA}$ & 0.405 & 163 & 323 & 6701 & (2.1) 2.2 & 201 & (3.3) 3.4 & 0.2 & 7.0 & 7.0 \\
\hline & MW & 0.250 & 167 & 280 & 7683 & (4.5) 4.5 & 175 & (1.5) 1.5 & 0.1 & 6.0 & 5.9 \\
\hline & $\mathrm{AS}+\mathrm{MW}$ & 0.185 & 159 & 227 & 9755 & (4.3) 4.1 & 138 & (1.8) 1.8 & - & 4.0 & 4.2 \\
\hline & $0.1 \mathrm{M} \mathrm{NaCl}$ & 0.110 & 121 & 277 & 11720 & (6.4) 6.6 & 114 & (10.5) 10 & - & 3.2 & 3.1 \\
\hline & AS & 0.105 & 130 & 316 & 17800 & $(5.2) 5.5$ & 75.6 & (2.85) 2.9 & - & 2.2 & 2.3 \\
\hline \multirow[t]{7}{*}{ Ir } & $\mathrm{CP}$ & 0.240 & 395 & 226 & 17 & (6.5) 6.7 & 64 & (35) 35.8 & - & 3298 & 3604 \\
\hline & $\mathrm{CP}+\mathrm{AS}$ & 0.235 & 317 & 224 & 33 & (6.8) 6.8 & 129 & (22) 29 & - & 1652 & 1737 \\
\hline & MW & 0.120 & 208 & 324 & 6365 & (4.5) 4.4 & 211 & (1.5) 1.5 & - & 8.6 & 8.6 \\
\hline & $\mathrm{CA}$ & 0.320 & 203 & 191 & 8344 & (2.1) 2.3 & 2.2 & (3.3) 3.4 & - & 4.1 & 5.1 \\
\hline & $\mathrm{AS}+\mathrm{MW}$ & 0.255 & 169 & 278 & 11235 & (4.3) 4.2 & 120 & (1.8) 1.8 & - & 4.0 & 4.1 \\
\hline & AS & 0.215 & 154 & 288 & 18294 & (5.2) 5.8 & 73.5 & (2.9) 2.7 & 0.3 & 2.4 & 2.4 \\
\hline & $0.1 \mathrm{M} \mathrm{NaCl}$ & 0.200 & 153 & 253 & 17843 & (6.4) 6.8 & 75 & (10.5) 9.9 & 0.4 & 2.4 & 2.3 \\
\hline \multirow[t]{7}{*}{$\mathbf{A u}$} & $\mathrm{CP}$ & 0.230 & 172 & 176 & 85 & (6.5) 6.8 & 985 & (35) 37.5 & 2.3 & 405 & 442 \\
\hline & $\mathrm{CP}+\mathrm{AS}$ & 0.265 & 125 & 181 & 1910 & (6.8) 6.8 & 137 & (22) 29.7 & 1.2 & 15 & 17 \\
\hline & MW & 0.035 & 154 & 208 & 11733 & (4.5) 4.4 & 95 & (1.5) 1.5 & 1.2 & 3.2 & 3.3 \\
\hline & $\mathrm{AS}+\mathrm{MW}$ & 0.035 & 118 & 136 & 84263 & (4.3) 4.2 & 15 & (1.8) 1.8 & - & 0.3 & 0.3 \\
\hline & $\mathrm{CA}$ & 0.400 & 147 & 302 & 83193 & (2.1) 2.2 & 16 & (3.3) 3.4 & 1.1 & 0.5 & 0.5 \\
\hline & $0.1 \mathrm{M} \mathrm{NaCl}$ & 0.035 & 103 & 177 & 59824 & (6.4) 6.5 & 22.5 & (10.5) 10 & 1.1 & 0.5 & 0.5 \\
\hline & AS & 0.080 & 101 & 239 & 293687 & (5.2) 5.4 & 3.7 & (2.9) 2.8 & 1.3 & 0.1 & 0.1 \\
\hline \multirow[t]{7}{*}{$\mathbf{C u}$} & $\mathrm{CA}$ & 0.015 & 283 & 111 & 1320 & (2.1) 2.3 & 1020 & (3.3) 3.0 & 1.4 & 23 & 26 \\
\hline & $\mathrm{CP}$ & 0.260 & 146 & 310 & 1833 & (6.5) 6.7 & 23 & (35) 38 & 1.0 & 23.7 & 23.5 \\
\hline & $\mathrm{CP}+\mathrm{AS}$ & 0.245 & 147 & 309 & 2340 & (6.8) 6.8 & 22 & (22) 29.8 & 0.5 & 18.5 & 18.5 \\
\hline & $0.1 \mathrm{M} \mathrm{NaCl}$ & -0.140 & 157 & 73 & 1603 & (6.4) 6.4 & 840 & (10.5) 10 & 0.1 & 13.6 & 13.5 \\
\hline & MW & -0.002 & 213 & 77 & 8827 & (4.5) 4.5 & 152 & (1.5) 1.5 & 0.5 & 2.7 & 2.8 \\
\hline & AS & -0.105 & 152 & 60 & 7218 & (5.2) 5.7 & 186 & (2.9) 2.8 & 0.8 & 2.6 & 2.6 \\
\hline & AS+MW & -0.105 & 152 & 60 & 7218 & (4.3) 5.6 & 101 & (1.8) 2.9 & 0.8 & 1.4 & 1.5 \\
\hline
\end{tabular}


International Journal of Scientific and Technological Research

ISSN 2422-8702 (Online), DOI: 10.7176/JSTR/5-4-14

Vol.5, No.4, 2019

Table 4. Elemental composition of metal surfaces at the end of experiment after during a week in different oral solution as wt $\%$ from EDS.

\begin{tabular}{|c|c|c|c|c|c|c|c|c|c|c|c|c|c|c|}
\hline \multirow{2}{*}{ Me } & \multirow{2}{*}{ Solution } & \multicolumn{13}{|c|}{ Percentage of element composition } \\
\hline & & Au & Pd & $\mathbf{R h}$ & A $\mathbf{g}$ & $\mathbf{P t}$ & $\mathbf{O}$ & $\mathbf{C}$ & $\mathbf{N}$ & $\mathbf{F e}$ & $\mathbf{C u}$ & $\mathbf{I r}$ & $\mathbf{C l}$ & Other \\
\hline \multirow[t]{4}{*}{ Ag } & Pure & & & & 100 & & & & & & & & & \\
\hline & AS & & & & 87 & & 9.0 & 1.8 & & & & & & \\
\hline & $\mathrm{CP}$ & & & & 71 & & 19.4 & 1.7 & & & & & & $5.5(\mathrm{P})$ \\
\hline & $\mathrm{CP}+\mathrm{AS}$ & & & & 74.8 & & & & & & & & 25.2 & \\
\hline \multirow[t]{4}{*}{ Pd } & Pure & & 99.8 & & & & & & & & & & & \\
\hline & $\mathrm{CP}$ & & 94.4 & & & & & 1.0 & & 2.2 & 1.5 & & & 0.6 \\
\hline & MW & & 96.6 & & & & & & & 1.7 & 1.8 & & & 1.1 \\
\hline & $\mathrm{CP}+\mathrm{AS}$ & & 96.1 & & & & & 0.9 & & 0.8 & 1.1 & & & 0.9 \\
\hline \multirow[t]{3}{*}{$\mathbf{P t}$} & Pure & & 1.50 & & 0.20 & 96 & & & & & & & & $0.6(\mathrm{Co}$ \\
\hline & $\mathrm{CP}$ & & & & & 92.5 & 2.8 & 5.0 & & & & & & \\
\hline & $\mathrm{CP}+\mathrm{AS}$ & & & & & 92 & 3.0 & 5.4 & & & & & & \\
\hline \multirow[t]{4}{*}{$\mathbf{R h}$} & Pure & & & 98.7 & & & & & & & & & & \\
\hline & $\mathrm{CP}$ & & & 95.6 & & & & 0.9 & & 1.0 & & & & 2.6 \\
\hline & $\mathrm{CP}+\mathrm{AS}$ & & & 87.1 & & & 8.7 & 1.4 & & 1.5 & & & & 1.6 \\
\hline & $\mathrm{CA}$ & & & 95.6 & & & & & & 2.2 & & & & 2.1 \\
\hline \multirow[t]{2}{*}{ Ir } & $\begin{array}{l}\text { Pure } \\
\text { CP }\end{array}$ & & & & & & 3.5 & & & & & $\begin{array}{l}99.9 \\
96.5\end{array}$ & & \\
\hline & $\mathrm{CP}+\mathrm{AS}$ & & & & & & 9.3 & 2.8 & & & & 94.1 & & \\
\hline \multirow[t]{4}{*}{ Au } & Pure & 100 & & & & & & & & & & & & \\
\hline & $\mathrm{CP}$ & 78.4 & & & & & 6.1 & 6.3 & 8.1 & 0.5 & & & & \\
\hline & MW & 97 & & & & & 4.0 & & & & & & & \\
\hline & $\mathrm{CP}+\mathrm{AS}$ & 87 & & & & & 4.8 & 0.3 & 6.5 & & & & & 1.05 \\
\hline \multirow[t]{4}{*}{$\mathrm{Cu}$} & Pure & & & & & & 1.7 & & & & 98 & & & \\
\hline & AS & & & & & & 14.2 & & & & 74 & & & $6.6(\mathrm{P})$ \\
\hline & $\mathrm{CP}+\mathrm{AS}$ & & & & & & 16.0 & & & & 72 & & & $7.2(\mathrm{P}$ \\
\hline & $\mathrm{CA}$ & & & & & & 4.2 & 3.7 & & & 92 & & & \\
\hline
\end{tabular}

Copper more corroded and dissolved in CA (Table 4). It can be formed complex product with citrate anion. For this reason, if gold containing copper, it is not suitable in CA. Silver corroded less in AS, MW and $\mathrm{NaCl}$ solution (Table 4). Because, insoluble silver chloride formed on the metal surface, but it more corroded in CP, it was formed soluble product (Table 5). Due to corrosion products of iridium are soluble in this solution (Table 5).

Table 5. Noble metal ions obtained in different oral solution after a week from ICP-OES/MS analysis.

\begin{tabular}{l|ccc|ccc|cc|cc|cc|cc|cc|c}
\hline Metal & \multicolumn{3}{|c|}{ Au } & \multicolumn{3}{c|}{ Pd } & \multicolumn{3}{c|}{ Rh } & \multicolumn{2}{c|}{ Cu } & \multicolumn{2}{c|}{ Ag } & \multicolumn{3}{c|}{ Pt } & \multicolumn{2}{c}{ Ir } \\
\hline Solution & MW & CP & AS+CP & CP & CP+AS & MW & CP & CP+AS & AS & CA & CP & AS & CP & CP+AS & CP & AS \\
ppm & - & - & - & 40 & 18 & - & 47 & 39 & 0.2 & 121 & 44 & - & 13 & - & 19 & 20 \\
\hline
\end{tabular}

Table 6. Pilling-Bedworth ratio $\left(\mathrm{V}_{\text {oxide }} / \mathrm{V}_{\text {metal }}=\mathrm{R}_{\mathrm{PB}}\right)$ of noble metal oxides

\begin{tabular}{lllllllllll}
\hline Metal oxide & $\mathrm{Au}_{2} \mathrm{O}_{3}$ & $\mathrm{IrO}_{2}$ & $\mathbf{A g O}$ & $\mathbf{P t O}_{2}$ & $\mathbf{C u O}$ & $\mathbf{R h}_{2} \mathrm{O}_{3}$ & $\mathbf{P d O}$ & $\mathbf{C u}_{2} \mathrm{O}$ & $\mathbf{P t O}$ & $\mathbf{A g}_{2} \mathrm{O}$ \\
\hline $\mathrm{R}$ & 6.01 & 8.3 & 3.21 & 2.45 & 1.77 & 1.73 & 1.68 & 1.65 & 1.56 & 1.52 \\
\hline
\end{tabular}

The ratio of the molar volume of metal oxide to metal (Pilling-Bedworth ratio) is given the following Eq.4. If the ratio is close to 1, the corrosion resistance is higher. For example, this ratio for aluminum is 1.28 . 


$$
\mathrm{R}_{P B}=\frac{V_{\text {oxide }}}{V_{\text {metal }}}=\frac{\rho_{\text {metal }} \times \boldsymbol{m}_{\text {oxide }}}{\rho_{\text {oxide }} \times \boldsymbol{m}_{\text {metal }}}
$$

Where $V_{\text {oxide }}$ is the volume of metal oxide; $V_{\text {metal }}$ is the volume of metal; $\rho_{\text {oxide }}$ is the density of metal oxide; $\rho_{\text {metal }}$ is the density of metal; $m_{\text {oxide }}$ is the mass of metal oxide; $m_{\text {metal }}$ is the mass of metal.

If corrosive solutions contain strong oxidative agents such as $\mathrm{CP}$, it will be higher valence oxides. Their form on the metal surfaces Pilling-Bedworth ratios is higher. For example, there ratios calculated using molar weight and density of metal and metal oxide are for $\mathrm{PtO} 1.56, \mathrm{PtO}_{2} 2.45, \mathrm{Cu}_{2} \mathrm{O} 1.65, \mathrm{CuO} 1.77$, $\mathrm{TiO}$ 1.22, $\mathrm{Ti}_{2} \mathrm{O}_{3} 1.48, \mathrm{WO}_{2} 1.88, \mathrm{WO}_{3} 3.41$ [26-43]. CP or its reaction products with metals (Eq.4) can be adsorption on gold, platinum and silver surface or CP reacts with these noble metals [39]. Therefore, $\mathrm{C}, \mathrm{N}$ and $\mathrm{O}$ observed on the metal surface from the EDX analysis of gold, platinum and silver in this solution (Table 4). These elements come from urea, they were showed on the Ni-Cr alloy in lactic acid containing saliva solution [44]. The composition of the surface can be changed by forming oxide or cation adsorption on the metal surface and it increase percent of trace elements. These results can be explained by adsorption urea anion on oxide or pure gold surface. In addition, more less mass loss are also confirmed with it. These results showed that noble metals used in higher corrosive solution are not very allergic [45-46].

$$
\mathrm{Au}(\mathrm{k})+\mathrm{CH}_{6} \mathrm{~N}_{2} \mathrm{O}_{3}(\mathrm{aq}) \rightarrow 2 \mathrm{H}_{2} \mathrm{O}(\mathrm{s})+\mathrm{AuCH}_{2} \mathrm{~N}_{2} \mathrm{O}(\mathrm{aq})
$$

EDX analysis of Pd and Rh in very corrosive solution was shown that obtained less amount of $\mathrm{C}$ and $\mathrm{O}$, and this result showed that corrosion products of $\mathrm{Pd}$ and $\mathrm{Rh}$ are more soluble in $\mathrm{CP}$ containing solutions. This change means the elements ratio on the metal surface (Table 4) [42]. In acidic solution, reduction reaction is $\mathrm{H}^{+}$ion to $\mathrm{H}_{2}$ at the metal oxidation. This causes increase at $\mathrm{pH}$ and decrease at conductivity in the studied acidic medium. If the solution of $\mathrm{pH}$ is higher, reduction reaction is reducing $\mathrm{O}_{2}$ to $\mathrm{OH}^{-}$. It increased solution $\mathrm{pH}$ values.

\section{Results}

- Artificial saliva (AS) containing carbamide peroxide (CP) is higher aggressive solution for all noble metals than copper.

- Corrosion rates can be calculated from Stern-Geary equation using the slopes of linear polarization lines obtained by drawing current-potential curves values at the near the corrosion potential on anodic and cathodic Tafel slopes.

- Corrosion rates are almost the same both the Stern-Geary and Tafel methods. It is indicated that the $\mathrm{R}_{\mathrm{LP}}$ calculated from the linear polarization more accurate resistance.

- Corrosion rates calculated from mass loss method are smaller than calculated other methods, it shows that all of the corrosion products are not dissolve.

- Copper is highly soluble in 0.1M CA environment and less soluble in CP environment

- Gold metal immersed in high corrosive solution (CP) showed that the protective layer occurred on the surface. But, copper metal shows different behavior in the CP containing solution. It showed that less corrosion. Thus, these data show that gold-copper alloys can be higher resist against to corrosion in bleaching agent material (CP) than pure gold metal.

- Lowering of mass losses showed that the corrosion resistance was improved on the noble metal surface because of the protective oxide layer.

\section{Acknowledgements}

The authors gratefully acknowledge financial support from Ankara University (Scientific Research Project No: 17H0430003) 
International Journal of Scientific and Technological Research

ISSN 2422-8702 (Online), DOI: 10.7176/JSTR/5-4-14

Vol.5, No.4, 2019

\section{References}

1. Xingya Jiang, Bujie Du, Yingyu Huang, and Jie Zheng, Review, Nano Today, (2018) 21, 106.

2. Xuesong Zhang, Yongjun Chen, and Junling Hu, Prog. Aerospace Sci., (2018) 97, 22.

3. A. Işıldar, E. R. Rene, E. D. van Hullebusch, and P. N. L. Lens, Resour. Cons. Recyc., (2018) 135, 296.

4. S. Medici, M. Peana, V. M. Nurchi, J. I. Lachowicz, G. Crisponi, and M. A. Zoroddu, Coordination Chemistry

Reviews, (2015) 284, 329.

5. S. Cherevko, J. Electroanal. Chem., (2017) 787, 11.

6. M. A. Zoroddu, S. Medici, A. Ledda, V.M. Nurchi, J. I. Lachowicz, and M. Peana, Curr. Med. Chem., (2014) 21 (33), 3837.

7. Xingya Jiang, Bujie Du, Yingyu Huang, and Jie Zheng, Review, Nano Today, (2018) 21, 106.

8. C. Zeng, Y. Chen, G. Li, and R. Jin, Chem. Mater., (2014) 26, 2635.

9. G. Li, C. Zeng, and R. Jin, J. Am. Chem. Soc., (2014) 136, 3673.

10. Y. Yu, X. Chen, Q. Yao, Y. Yu, N. Yan, and J. Xie, Chem. Mater., (2013) 25, 946.

11. C. P. Joshi, M.S. Bootharaju, and O.M. Bakr, J. Phys. Chem Lett., (2015) 6, 3023.

12. A. Desireddy, B.E. Conn, J. Guo, B. Yoon, R.N. Barnett, B.M. Monahan, K. Kirschbaum, W.P. Griffith, R.L.

Whetten, and U. Landman, Nature, (2013) 501, 399.

13. S. I. Tanaka, J. Miyazaki, D.K. Tiwari, T. Jin, and Y. Inouye, Angew. Chem., (2011) 123, 451.

14. T. Imaoka, H. Kitazawa, W.J. Chun, S. Omura, K. Albrecht, K. Yamamoto, J. Am. Chem.Soc., (2013) 135, 13089.

15. J. D. Erickson, E.G. Mednikov, S.A. Ivanov, and L.F. Dahl, J. Am. Chem. Soc., (2016) 138, 1502.

16. E. G. Mednikov, and L.F. Dahl, Philos. Trans. R. Soc. Lond., (2010) 368, 1301.

17. Jinli Qiao, Yuyu Liu, Feng Hong, Jiujun Zhang, Chem.Soc.Rev., (2014) 43, 631.

18. H. Yamamoto, P. Maity, R. Takahata, S. Yamazoe, K. Koyasu, W. Kurashige, Y. Negishi, T. Tsukuda, J. Phys.

Chem. C, (2017) 121, 10936.

19. M. Pourbaix, (1974). National Association of Corrosion Engineers, USA: Houston Texas.

20. A. Pavlisic, P. Jovanovic, V.S. Selih, M. Sala, N. Hodnik, S. Hocevar, and M. Gaberscek, Chem. Commun., (2014) 50, 3732.

21. Z. Wang, E. Tada, and A. Nishikata, ECS Trans. (2015) 69, 255.

22. B. R. Shrestha, A. Nishikata, and T. Tsuru, J. Electroanal. Chem., (2012) 665, 33.

23. G. Inzelt, B. Berkes, and Á. Kriston, Electrochim. Acta, (2010) 55, 4742. 
24. N. Hodnik, P. Jovanovic, A. Pavlisic, B. Jozinovic, M. Zorko, M. Bele, V.S. Selih, M. Sala, S. Hocevar, and $\mathrm{M}$.

Gaberscek, J. Phys. Chem., C, (2015) 119, 10140.

25. M. S. Antelman, H. J. Harris, (1982) The Encyclopedia of Chemical Electrode Potentials, New York: Plenum Press.

26. R. C. Weast, (1972). Handbook of Chemistry and Physics, Ohio: Cleveland.

27. M. Çataltepe, PhD Thesis (Univ. Süleyman Demirel, Isparta, Türkiye, 2011).

28. H. W. Roberts, D.W. Berzins, B.K. Moore, D.G. Charlton, Metal-Ceramic Alloys in Dentistry: A Review. J. Prosthodontics, (2009) 18, 188.

29. I. Nikellis, A. Levi, and S. Zinelis, J. Prosthet Dent., (2005) 94 (5),9.

30. R. Laeijendecker, S.K. Dekker, P.M. Burger, P.G. Mulder, T. Van Joost, and M.H. Neumann, Arch Dermatol, (2004) 140 (12), 8.

31. M. J. McCullough, and M.J. Tyas, Int Dent J. (2008) 58 (1), 9.

32. S. P. Kedici, A.A. Aksüt, M.A. Kılıçarslan, G. Bayramoğlu, and K. Gökdemir, J. Oral Rehabilitation, (1998) 25 (10), 8.

33. G. Bayramoğlu, T. Alemdaroğlu, S. Kedici, and A.A. Aksüt, J.Oral Rehabilitation, (2000) 27 (7), 75 .

34. S. Viennot, F. Dalard, M. Lissac, B. Grosgogeat, Eur.J. Oral. Sci., (2005) 113, 90.

35. M. Kathega, S. Nagarajan, N. Rajendran, Electrochem. Acta, (2010) 55, 2201.

36. D. M. Sarantopoulos, K. A. Beck, R. Holsen, D. W. Berzins,, J. Prosthentic Dentistry, (2011) 105 (1), 35 .

37. Irma C. Matos, Ivan N. Bastos, Marília G. Diniz, Mauro S. de Miranda, J. Prosthentic Dentistry, (2015) 114 (2), 1.

38. A. J. Bard, L. R. Faulkner, Electrochemical Methods, (John Wiley \& Sons, Inc., New York, 1980).

39. M. A. Ameer, E. Khamis, and M. Al-Motlaq, Electrochem. Acta, (2004) 50 (1), 141.

40.V. Penta, C. Pirvu, and I. Demetrescu, Apcbee Procedia, (2013) 7, 67.

41. E. Tamam, A. Kevser Aydın, and S. Bilgiç, J. Prosthodontics, (2014) 23 (7), 549.

42. H. S. Tuna, N. Özçiçek Pekmez, and F. Canlı, Dental Materials, (2009) 25 (9), 1096.

43. G. Znang, Improving IC yield with protective ceramics, (Semiconductor Int., 2000).

44. B. Bowers, T. John Wolan, Z. Cai, and D. Bumgardner Joel, Dental Materials, (2008) 24 (3), 378.

45. A. Johnson, and T. Shiraishi, (2014). Biocompatibility of Precious Metals for Biomedical Applications. Elsevier.

46. S. Scott, De Rossi, S. Martin Greenberg, and J. Am. Dent. Assoc., (1998) 129, 1435. 